\title{
Anti-inflammatory therapy for feline immunodeficiency virus infection and associated AIDS-like syndrome
}

\section{Arne Lucas ten Hoeve* and Arden Leander van Arnhem}

ALH Nutritional Research, Utrecht, Netherlands

*Correspondence: a.l.tenhoeve@alhnutrition.nl

Feline immunodeficiency virus (FIV) is a lentivirus that can infect several feline species, among them the domestic cat. Related lentiviruses are prevalent in non-domestic felids (Olmsted et al., 1992). The isolation of FIV from cats who while having an immunodeficiency-like illness were seronegative for Feline leukemia virus (FeLV), was first described in 1987 (Pedersen et al., 1987). FIV is classified into five phylogenetic subtypes, A through E, according to the nucleotide sequence diversity in the env gene that encodes for the viral envelop proteins. Subtypes A and B are most prevalent worldwide (Samman et al., 2011). The seroprevalence differs between regions, with $1-14 \%$ in clinically asymptomatic domestic cats and up to $44 \%$ in sick cats (Hosie et al., 2009).

Feline immunodeficiency virus transmission occurs naturally mainly through biting, but vertical transmission between mother and kittens is also possible (Yamamoto et al., 1989). Transmission occurs more easily when an uninfected cat is exposed to infected cells, although lower levels of the virus are also present in colostrum, saliva, plasma, and seminal fluid (Yamamoto et al., 2007). After acute infection FIV can cause a AIDS-like syndrome in domestic cats, with many similarities to HIV-induced AIDS in man (Elder et al., 2010). Progression of the chronic lentivirus infection is associated with a decline in $\mathrm{CD} 4+\mathrm{T}$ lymphocytes and CD4+:CD8+ ratio during a asymptomatic phase. During this period plasma virus load remains stable (Hosie et al., 2009). When the CD4+ T lymphocyte count falls below a certain number immune dysfunction will become apparent, accompanied by secondary and opportunistic infections (Willett et al., 1997). In addition to the ability to infect CD4+ T lymphocytes, FIV also infects several other immune cells, including monocytes/macrophages, B cells, CD4+CD25+ T cells, and CD8+ $\mathrm{T}$ cells (Yamamoto et al., 2007).
Currently practiced therapy focuses on immune stimulation, vaccination, and treatment of secondary diseases. Immune stimulation has been suggested in the form of GM-CSF, IFN-alpha, and IFN-tau among others (Arai et al., 2000; Pedretti et al., 2006; Chon and Bixler, 2010). These therapies are based on the notion that the CD4+ T lymphocyte depletion in feline AIDS is the direct consequence of viral killing by FIV (the "viral killing hypothesis"). In this theory high turnover of T lymphocytes and eventually exhaustion is a response to viral destruction of CD4+ T lymphocytes. It has also been suggested however, that activation-induced CD4+ T lymphocyte death may be a major factor in progression to AIDS in humans (Groux et al., 1992; Hazenberg et al., 2003), which corresponds with the absence of CD4+ T lymphocyte decline in naturally Simian immunodeficiency virus (SIV) infected Sooty Mangabeys (Silvestri et al., 2003). These primates show a high viral load, but limited SIV CD4+ T lymphocyte cytopathicity. Therefore chronic (hyper-) activation of the immune system may also play a significant role in FIV pathogenesis
(Figure 1). This hyper-activation is seen in both CD4+ and CD8+ Tlymphocyte populations, with a rise in $\mathrm{B} 7+\mathrm{CTLA} 4+$ phenotype, and increase in B lymphocyte polyclonal responses (Tompkins and Tompkins, 2008). The B7+CTLA4+ T lymphocytes cause an induction of anergy and apoptosis through $\mathrm{T}-\mathrm{T}$ lymphocyte interactions, which leads to CD4+ T lymphocyte depletion.

Partly the depletion of CD4+ T lymphocytes may also be due to the activation of CD4+CD25+ $\mathrm{T}$ regulatory (Treg) cells in FIV-infected cats. Previous studies suggested that a proper immune response is lost during the acute phase FIV infection (Mexas et al., 2008). It's possible that CD4+CD25+ T regulatory lymphocytes induce anergy in CD4+ and CD8+ T cells (Vahlenkamp et al., 2004). This knowing, it could be meaningful investigating which mechanisms cause the activation of CD4+CD25+ Treg cells and if it can be suppressed effectively during the acute phase of FIV infections, without losing an effective immune response. CD4+ and CD8+T-cells functioning may improve when CD4+CD25+ Treg cells are suppressed and slow progression to AIDS.

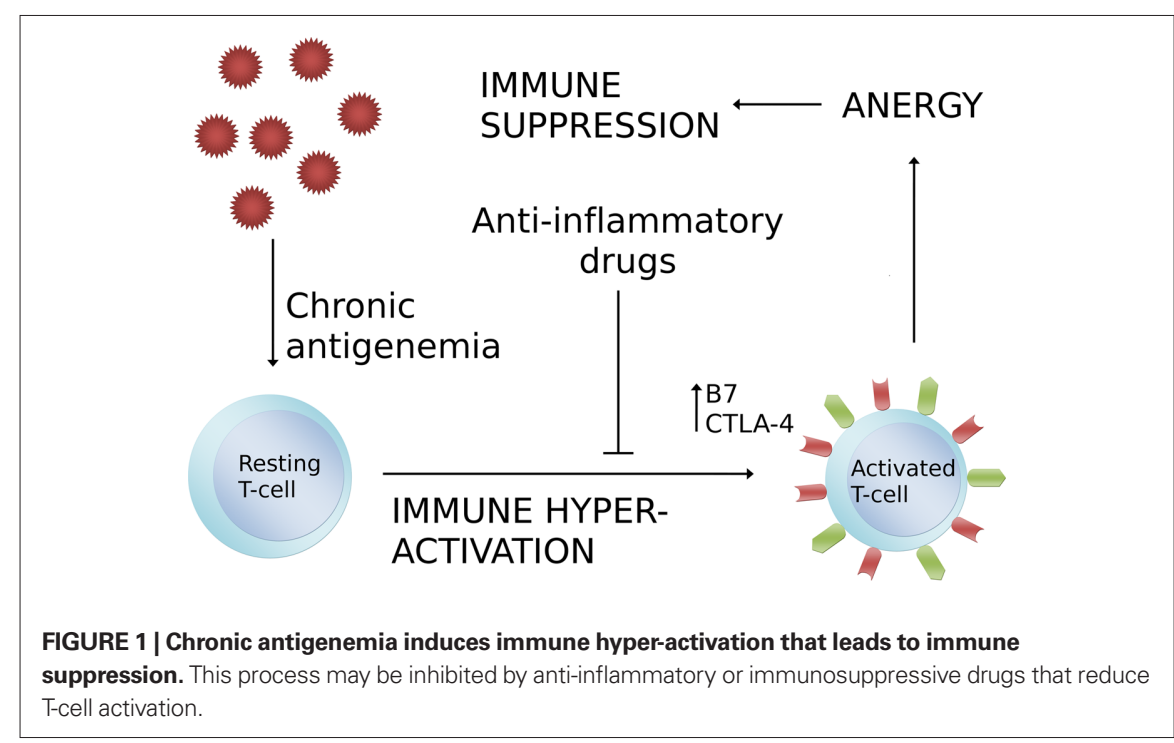


In light of this evidence it is important to explore the effectiveness of immunosuppressive or anti-inflammatory treatment in the prevention of progression to AIDS in FIV-infected cats. Suggested pharmaceuticals for this type of treatment for HIV are cyclosporin A and corticosteroids (Groux et al., 1992; Lawn et al., 2001). It should however be noted that although this type of treatment may diminish the detrimental effect of immune hyper-activation, antiretroviral drugs, that for example inhibit FIV enzymes (Savarino et al., 2007), should be used or developed to alleviate the potential effects of immunosuppression on viral replication.

\section{REFERENCES}

Arai, M., Darman, J., Lewis, A., and Yamamoto, J. K. (2000). The use of human hematopoietic growth factors (rhGM-CSF and rhEPO) as a supportive therapy for FIV-infected cats. Vet. Immunol. Immunopathol. 77, 71-92.

Chon, T. W., and Bixler, S. (2010). Interferon-tau: current applications and potential in antiviral therapy. J. Interferon Cytokine Res. 30, 477-485.

Elder, J. H., Lin, Y. C., Fink, E., and Grant, C. K. (2010). Feline immunodeficiency virus (FIV) as a model for study of lentivirus infections: parallels with HIV. Curr. HIV Res. 8, 73-80.

Groux, H., Torpier, G., Monté, D., Mouton, Y., Capron,A., and Ameisen, J.C. (1992). Activation-induced death by apoptosis in CD4+ T cells from human immunodeficiency virus-infected asymptomatic individuals. J. Exp. Med. 175, 331-340.

Hazenberg, M. D., Otto, S. A., van Benthem, B. H., Roos, M. T., Coutinho, R.A., Lange, J. M., Hamann, D., Prins, M., and Miedema, F. (2003). Persistent immune activation in HIV-1 infection is associated with progression to AIDS. AIDS 17, 1881-1888.
Hosie, M. J., Addie, D., Belák, S., Boucraut-Baralon, C., Egberink, H., Frymus, T., Gruffydd-Jones, T. Hartmann, K., Lloret, A., Lutz, H., Marsilio, F., Pennisi, M. G., Radford, A. D., Thiry, E., Truyen, U., and Horzinek, M. C. (2009). Feline immunodeficiency. ABCD guidelines on prevention and management. J. Feline Med. Surg. 11, 575-584.

Lawn, S. D., Butera, S. T., and Folks, T. M. (2001). Contribution of immune activation to the pathogenesis and transmission of human immunodeficiency virus type 1 infection. Clin. Microbiol. Rev. 14, 753-777.

Mexas, A. M., Fogle, J.E., Tompkins, W.A., and Tompkins, M. B. (2008). CD4+CD25+ Regulatory T Cells are infected and activated during acute FIV infection. Vet. Immunol. Immunopathol. 126, 263-272.

Olmsted, R. A., Langley, R., Roelke, M. E., Goeken, R. M., Adger-Johnson, D., Goff, J. P., Albert, J. P., Packer, C. Laurenson, M. K., and Caro, T. M. (1992). Worldwide prevalence of lentivirus infection in wild feline species: epidemiologic and phylogenetic aspects. J. Virol. 66, 6008-6018.

Pedersen, N. C., Ho, E. W., Brown, M. L., and Yamamoto, J. K. (1987). Isolation of a T-lymphotropic virus from domestic cats with an immunodeficiency-like syndrome. Science 235, 790-793.

Pedretti, E., Passeri, B., Amadori, M., Isola, P., Di Pede, P., Telera, A., Vescovini, R., Quintavalla, F., and Pistello, M. (2006). Low-dose interferon-alpha treatment for feline immunodeficiency virus infection. Vet. Immunol. Immunopathol. 109, 245-254.

Samman, A., McMonagle, E. L., Logan, N., Willett, B. J., Biek, R., and Hosie, M. J. (2011). Phylogenetic characterisation of naturally occurring feline immunodeficiency virus in the United Kingdom. Vet. Microbiol. 150, 239-247.

Savarino, A., Pistello, M., D’Ostilio, D., Zabogli, E., Taglia, F., Mancini, F., Ferro, S., Matteucci, D., De Luca, L. Barreca, M. L., Ciervo, A., Chimirri, A., Ciccozzi, M., and Bendinelli, M.(2007). Human immunodeficiency virus integrase inhibitors efficiently suppress feline immunodeficiency virus replication in vitro and provide a rationale to redesign antiretroviral treatment for feline AIDS. Retrovirology 4, 79.
Silvestri, G., Sodora, D. L., Koup, R. A., Paiardini, M., O’Neil, S. P., McClure, H. M., Staprans, S. I., and Feinberg, M. B. (2003). Nonpathogenic SIV infection of sooty mangabeys is characterized by limited bystander immunopathology despite chronic highlevel viremia. Immunity 18, 441-452.

Tompkins, M. B., and Tompkins, W.A. (2008). Lentivirusinduced immune dysregulation. Vet. Immunol. Immunopathol. 123, 45-55.

Vahlenkamp, T.W., Tompkins, M. B., and Tompkins, A. F. (2004). Feline immunodeficiency virus infection phenotypically and functionally activates immunosuppressive $\mathrm{CD} 4{ }^{+} \mathrm{CD} 25^{+} \mathrm{T}$ regulatory cells. J. Immunol. 2004. 172, 4752-4761.

Willett, B. J., Flynn, J. N., and Hosie, M. J. (1997). FIV infection of the domestic cat: an animal model for AIDS. Immunol. Today 18, 182-189.

Yamamoto, J. K., Hansen, H., Ho, E. W., Morishita, T. Y., Okuda, T., Sawa, T. R., Nakamura, R. M., and Pedersen, N. C. (1989). Epidemiologic and clinical aspects of feline immunodeficiency virus infection in cats from the continental United States and Canada and possible mode of transmission. J. Am. Vet. Med. Assoc. 194, 213-220.

Yamamoto, J. K., Pu, R., Sato, E., and Hohdatsu, T. (2007). Feline immunodeficiency virus pathogenesis and development of a dual-subtype feline-immunodeficiency-virus vaccine. AIDS 21 , 547-563.

Received: 11 June 2011; accepted: 11 July 2011; published online: 19 July 2011.

Citation: ten Hoeve $A L$ and van Arnhem AL (2011)

Anti-inflammatory therapy for feline immunodeficiency virus infection and associated AIDS-like syndrome. Front. Microbio. 2:157. doi: 10.3389/fmicb.2011.00157

This article was submitted to Frontiers in Virology, a specialty of Frontiers in Microbiology.

Copyright (C) 2011 ten Hoeve and van Arnhem. This is an open-access article subject to a non-exclusive license between the authors and Frontiers Media SA, which permits use, distribution and reproduction in other forums, provided the original authors and source are credited and other Frontiers conditions are complied with. 